\title{
DETERMINATION CONVENTIONAL ROCK PROPERTIES FROM LOG DATA \& CORE DATA FOR UPPER NUBIAN SANDSTONE FORMATION OF ABU ATTIFEL FIELD
}

\author{
Adel Alabeed ${ }^{1}$, Zeyad Ibrahim ${ }^{2}$, Emhemed Alfandi ${ }^{3}$ \\ ${ }^{1,2}$ Faculty of Engineering, Aljabal Algharbi University \\ ${ }^{3}$ Faculty of Science, Sabratha University, Libya \\ ${ }^{3}$ Corresponding author: E-mail: alfandi73@yahoo.com
}

\begin{abstract}
A reservoir is a subsurface rock that has effective porosity and permeability which usually contains commercially exploitable quantity of hydrocarbon. Reservoir characterization is undertaken to determine its capability to both store and transmit fluid. Petrophysical well log and core data, in this paper, were integrated in an analysis of the reservoir characteristics by selecting of three productive wells. The selected wells are located at Abu Attifel field in Libya for Upper Nubian Sandstone formation at depth varied form 12921 to14330 ft. The main aim of this study is to compare the laboratory measurement of core data with that obtained from well log data in order to determine reservoir properties such as shale volume, porosity $(\Phi)$, permeability $(\mathrm{K})$, fluid saturation, net pay thickness. The plots of porosity logs and core porosity versus depth for the three wells revealed significant similarity in the porosity values. The average volume of shale for the reservoir was determined to be $22.5 \%$, and average permeability values of the three wells are above $150 \mathrm{md}$, while porosity values ranged from 9 to $11 \%$. Low water saturation 13 to $22 \%$ in the three wells indicates the wettability of the reservoir is water-wet.
\end{abstract}

Keyword: Reservoir characteristics, Sandstone, Well log, Abu Attifel, Libya

\section{Introduction}

Porosity and permeability are important parameters in the evaluation of reservoirs. Reservoir evaluation generally includes their identification, the determination of petrophysical parameters and the study of their economic significance (Frailey, etal, 2011). This paper discusses the methodology to determine porosities and permeability in Upper Nubian Sandstone formation of Abu Attifel field in Libya.

Accurate well log permeability are desirable because logs exist for all wells and because permeability is one of the most important parameters used to define reservoir performance (Whittake, 1985: SERRA, 1984 and Johnson, and Pile, 2006). Standard methods of estimating permeability from well logs are not accurate enough to provide reliable values and are not widely used. 
The Upper Nubian Sandstone is characterized by distinct relationships between porosity and acoustic interval transit times as well as between porosity and permeability (Gomez, Dvorkin, \& Vanorio, 2010). This paper also presents mathematical models for this lithology for the determination of porosity and permeability from well logs (Bassiouni 1994 and Abbas,2006).

Hence, reducing uncertainty and characterization of the reservoir in this paper will be accomplished by integration analysis of well log data, consisted of data from a Gamma Ray log, Neutron log, Density log, sonic log and Resistivity log, with core data.

\section{Paper objective, Scope of Study and Research Methodology}

The main objective of this study is to qualify and quantify Upper Nubian Sandstone formation of Abu Attifel field by selecting three key pilot wells in order to assess the expected flow capacity for the rest of wells in field.

Microsoft Excel will be used in this work for the computation of volume of shale, average porosity, water saturation and net pay thickness. For optimum result, core analysis data will be used to compare with the obtained petrophysical log data. This work will preclude many aspects of full petroleum engineering study; however, it will tend to accomplish those aspects that can be managed within the scope of undergraduate study.

\section{Abu Attifel field location \& Nubian Formation Description:}

The Nubian reservoir under this study is Abu Attifel field located in the South eastern part of the Sirte basin in the Libyan Desert, and lies approximately between $21^{\circ} 55^{\prime}$ and $22^{\circ} 20^{\prime}$ in longitude, $28^{\circ} 46^{\prime}$ and $28^{\circ} 55^{\prime}$ in latitude. Abu Attifel's main area field has been discovered in March 1968 and the oil production started in March 1972

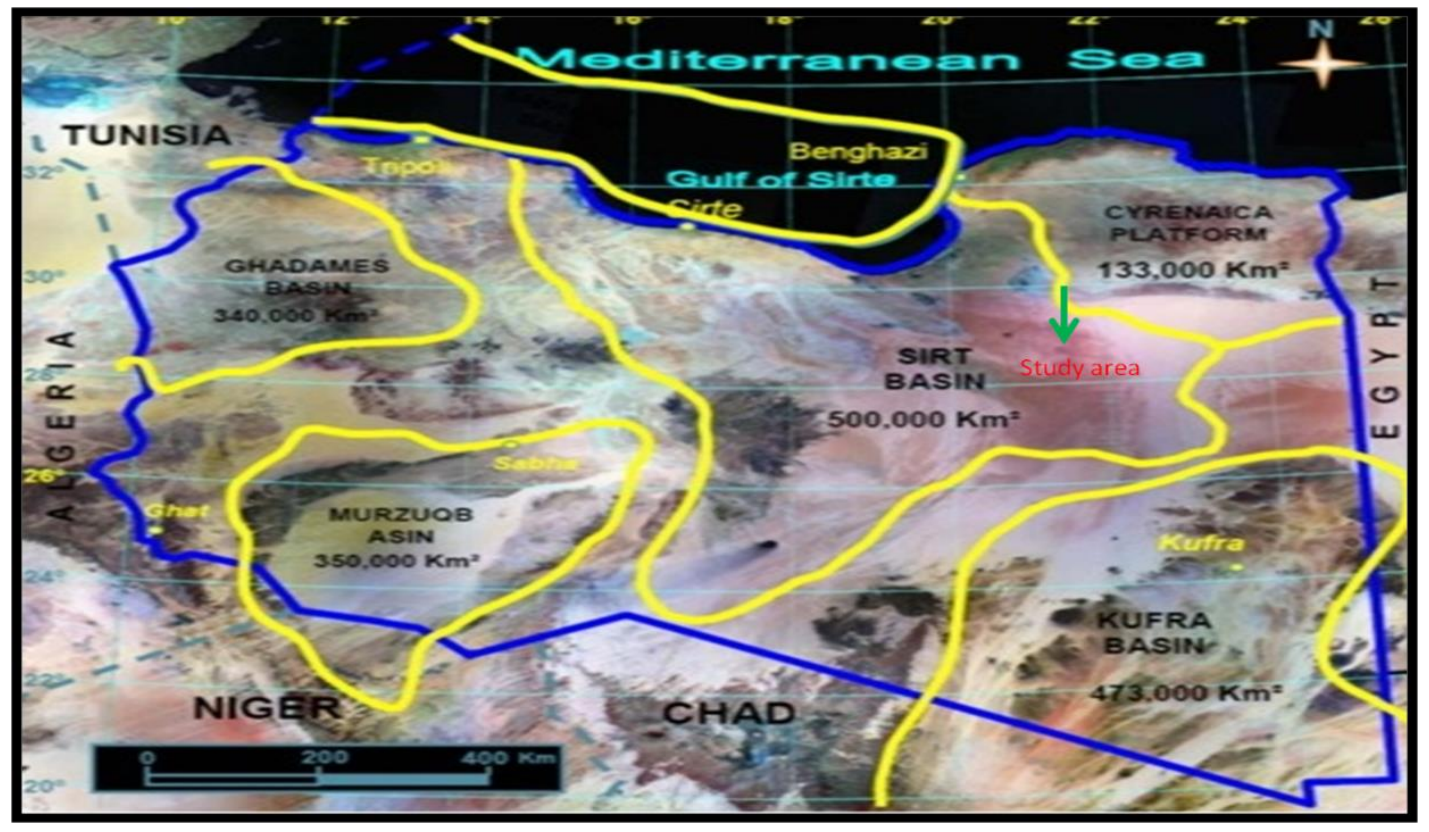

Figure (1): Abu Attifel field location map 
The Nubian formation is formed by the oil-bearing Lower Cretaceous Upper Nubian Sandstone as shown in figure (2), fine to coarse grained clean quartzitic sandstones with sporadic intercalations of fine grained shaly levels deposited in a deltaic-to-fluvial setting.

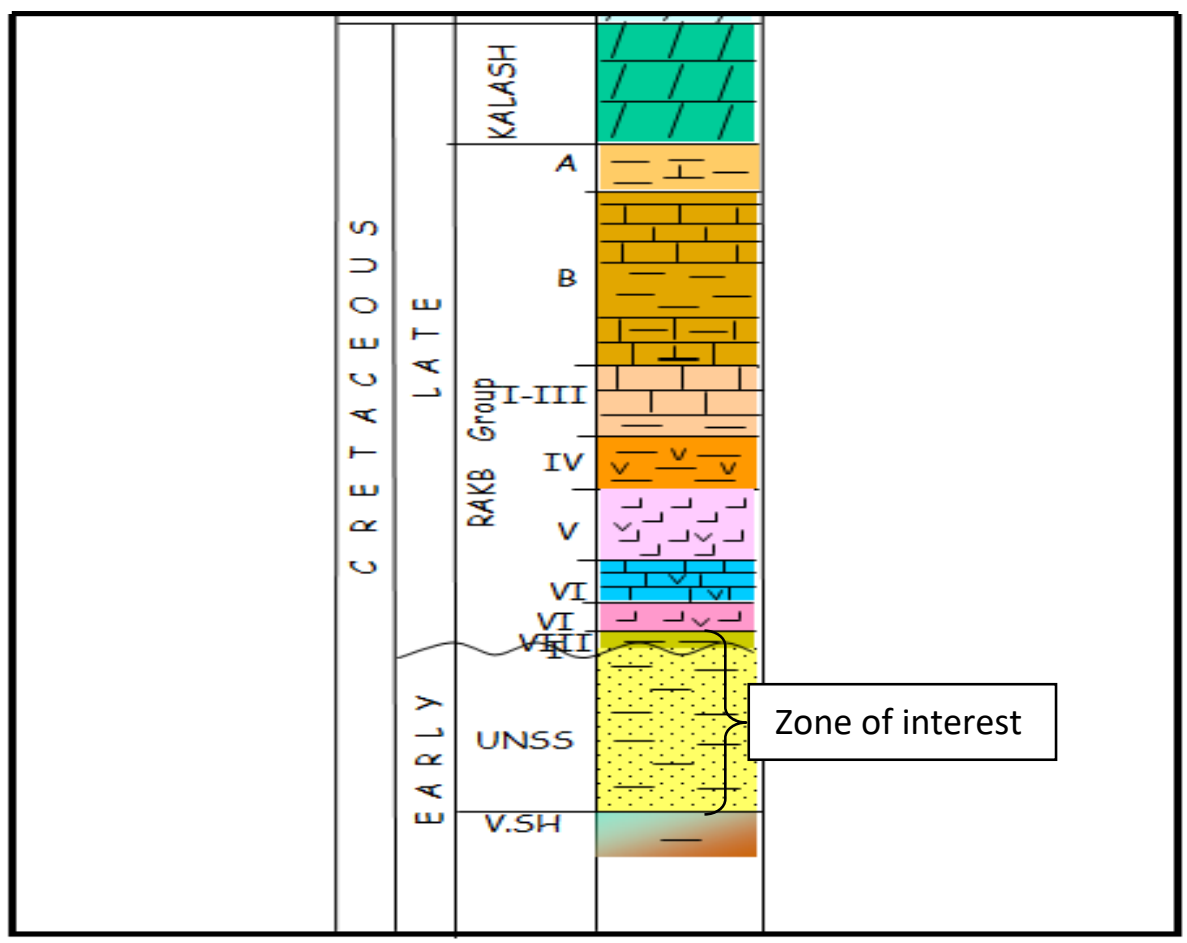

Figure (2): Lithology and zone of interest

The hydrocarbon play for this field consist of the Varicolour Shale act as a main source rock in the area for both the underlying Lower Nubian Sandstone and the overlying Upper Nubian sandstone formations as well as some inrtra reservoir shales which reached the maturation stage. The main reservoir rocks are the Lower and Upper Nubian sandstone reservoirs. The later is characterized by inter bedding of Fluvial and Lacustrine deposits, this alternation formed six sedimentary sequences, each starts with basal sandstone, referred as stage I and fining upward to end with clay which is referred as stage II. The clay beds of stage II has thickness ranging from thin poorly developed at the west area to thick well developed layers at the east area of the field.

\section{Materials and Methods}

\section{Data Availability}

The study was initiated with the collection of data (electronic copies of the wire line logs and core data), quality checks and feedbacks between Libyan Petroleum Institute (LPI) and Mellitah Oil \& Gas company representative. A detailed petrophysical review of the well was subsequently undertaken based on the wire line logs obtained from the three wells. 


\section{Estimation of Petrophysical Parameters}

\section{Net pay and Gross thickness}

The gross reservoir thickness $\mathrm{H}$, of the Wells was determined by defining the top and bottom of the reservoir sands through multiple formations across the wells. The net thickness which is the thickness of the reservoir was determined by defining basis for non reservoir and reservoir sands using the gamma ray log. This was carried out by drawing a shale baseline and sand baseline on the gamma ray log. The thicknesses of the shale, $h$ shale, within the reservoir sands were obtained and therefore, subtracted from the gross reservoir thickness. Hence, Net reservoir thickness, $\mathrm{h}=\mathrm{H}-\mathrm{h}$ shale was obtained for all the reservoir in Abu Attifel field ( Ahmed, 2010).

\section{Shale and Clay Volume}

The minimum and maximum read of gamma ray was used to compute shale volume as shown in equation no.1.

$$
V C L=\left(G R_{\log }-G R_{\min }\right) /\left(G R_{\max }-G R_{\min }\right)
$$

\section{Where:}

VCL $=$ Volume of Clay

GR $\log =$ Gamma Ray Log reading of formation

GRmin = Gamma Ray Matrix (Clay free zone)

GR $\max =$ Gamma Ray Shale $(100 \%$ Clay zone $)$

\section{Porosity}

Total porosity was calculated from density log as shown in the following relationship [3]:

$$
\Phi=(\rho m a-\rho b) /(\rho m a-\rho f)
$$

\section{Where:}

$\Phi=$ the porosity of the rock, fraction.

$\rho b=$ the bulk density of the formation, $\mathrm{g} / \mathrm{cm} 3$.

$\rho \mathrm{ma}=$ the density of the rock matrix, $\mathrm{g} / \mathrm{cm} 3$.

$\rho f=$ the density of the fluids occupying the porosity, $\mathrm{g} / \mathrm{cm} 3$.

\section{Effective porosity was estimated according to equation no. 3}

$$
\Phi \mathrm{e}=\Phi *(1-\mathrm{VCL})
$$

\section{Where:}

$$
\begin{aligned}
& \Phi e=\text { Effective porosity } \\
& (\rho \mathrm{ma}=2.65 \mathrm{~g} / \mathrm{cc}, \rho \mathrm{f}=1.0 \mathrm{~g} / \mathrm{cc})
\end{aligned}
$$

Water Saturation 
Archie Equation was used to calculate the water saturation as shown in equation 4 (Tiab and Donaldson 2004).

$$
\mathbf{S w}=(\mathbf{a} \cdot \mathbf{R w} / \Phi \mathbf{\Phi} \cdot \mathbf{R t})^{(1 / n)}
$$

\section{Where:}

$\mathrm{S}_{\mathrm{w}}=$ water saturation, fraction.

$\mathrm{Rw}=$ water resistivity $(=0.017 \mathrm{ohm} . \mathrm{m})$ from lab.

$\mathrm{R}_{\mathrm{t}}=$ true resistivity of formation containing hydrocarbons and formation water, ohm.m.

$\mathrm{n}=$ saturation exponent, $(=2)$.

$\mathrm{F}=$ formation resistivity factor, ohm.m

\section{Net Pay}

A porosity cut-off of $7 \%$ was used along with a shale volume cut-off of $31 \%$ to define the quality of the reservoir rock. Water saturation, $\mathrm{Sw}$, cut-off value of $50 \%$ was used to define pay. The reservoirs were defined by the porosity greater than $7 \%$ and shale volume less than $30 \%$. For the net pay, if the water saturation within the reservoir is less than $50 \%$, it is considered to contain hydrocarbon.

\section{Petrophysical Evaluation of the Reservoirs}

\section{Well-1}

The well in this reservoir has good net pay thicknesses $756 \mathrm{ft}$. table (1). The average density derived porosity for the reservoir is about $11.4 \%$, which indicates low porosity. The average water saturation value (Archie, 1942) is $(13.5 \%)$ that is indication the hydrocarbon saturation is high. The volume of shale (Vshale) is about $14.80 \%$ so that their presence cannot block rock channel, which allow fluids to flow from reservoir to the well. A plot of formation depth against porosity for well 1 indicates a decrease in porosity with depth figure (3). This is due to compaction caused by overburden pressure from overlying rocks. 


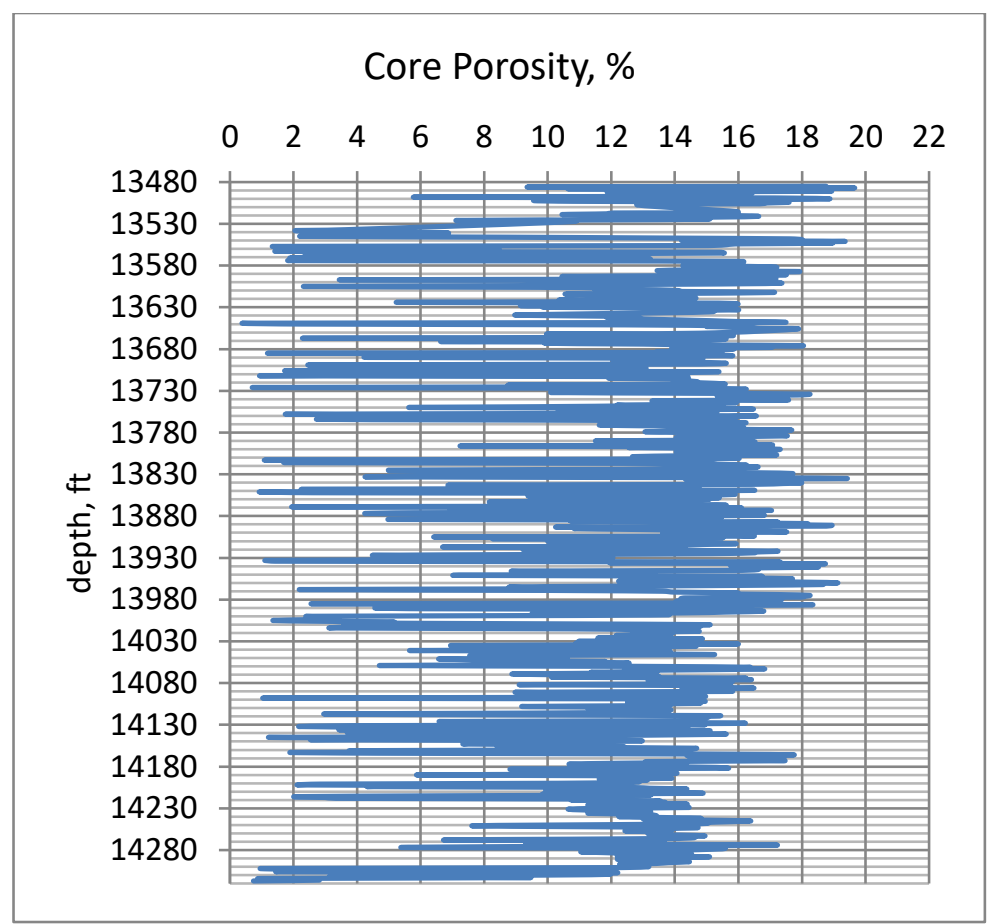

Figure (3): core porosity versus depth for well no.1

\section{Well-2}

The well in this reservoir has high net pay thicknesses 996ft. Table (1). The average density derived porosity for the reservoir is about $10.2 \%$, which indicates moderate porosity. The average water saturation is $(18.6 \%)$ that is indication the hydrocarbon saturation is high. The volume of shale (Vshale) is about $27.30 \%$ this means that their presence cannot block rock channel, and the fluids flow from reservoir to the well. A plot of formation depth against porosity for well 2 indicates a decrease in porosity with depth figure (4). 


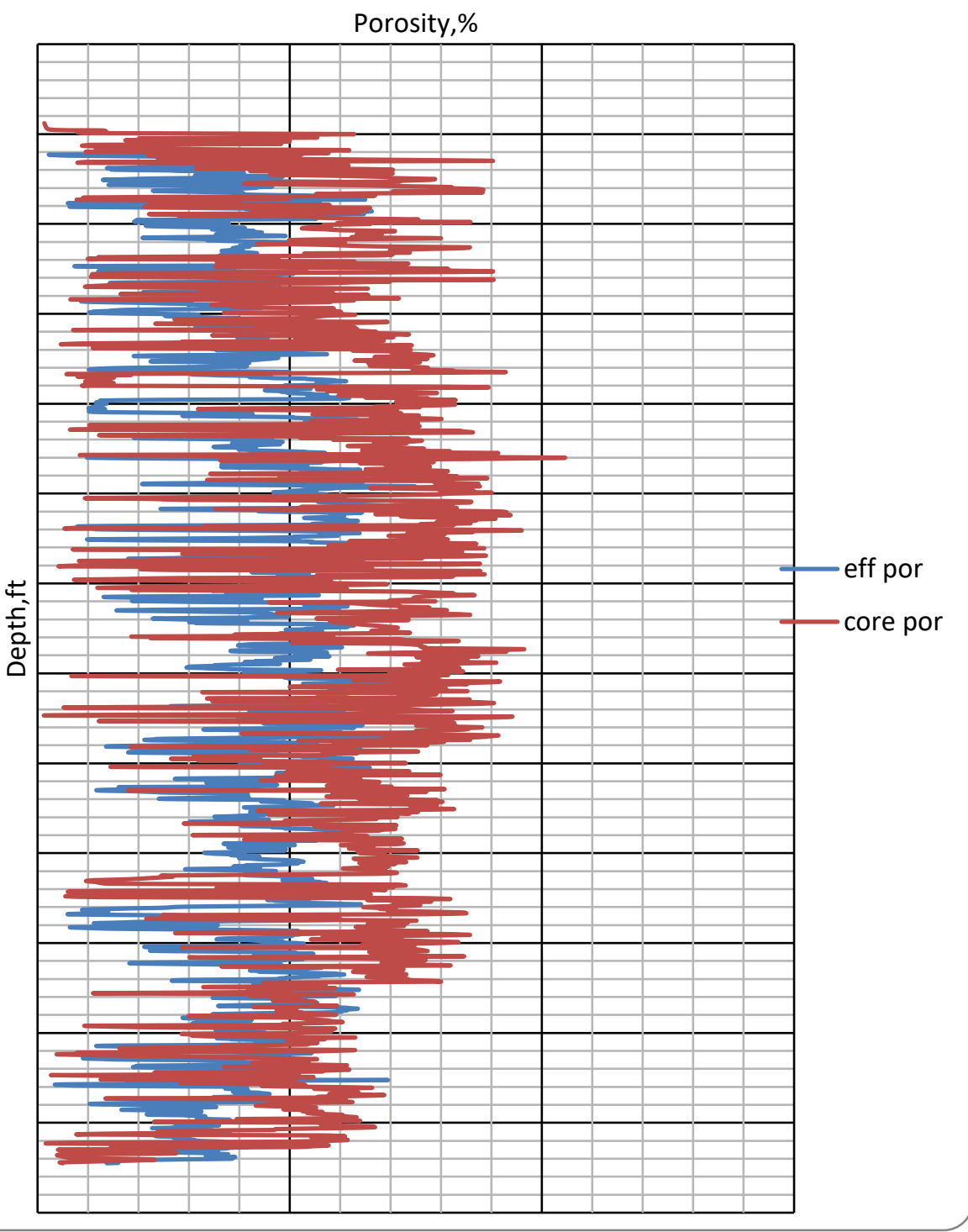

Figure (4): core porosity and effective porosity versus depth for well no.2

\section{Well-3}

The well in this reservoir has net pay thicknesses $291 \mathrm{ft}$, which is considered as moderate. Table (1). The average density derived porosity for the reservoir is about 9.9\%, which indicates moderate porosity figure (5). The average water saturation is $(22.5 \%)$ which indicate high hydrocarbon saturation. The volume of shale (Vshale) is about $25.31 \%$, which enable the fluids to flow through rock channel into the wellbore from the reservoir. 


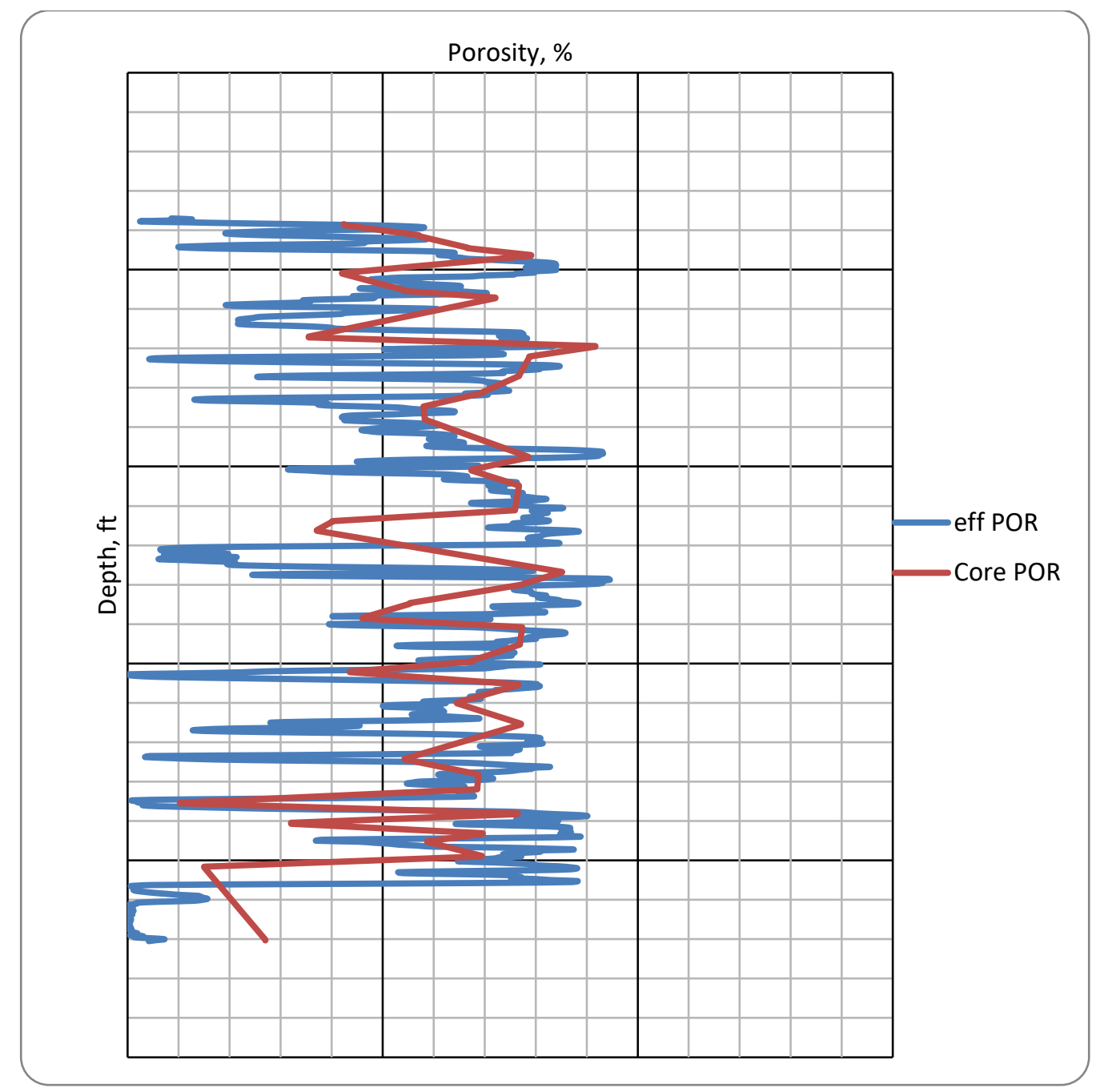

Figure (5): core porosity and effective porosity versus depth for well no.3

Table (1): Average Petrophysical Values for three wells

\begin{tabular}{|c|c|c|c|c|c|c|c|c|c|}
\hline $\begin{array}{c}\text { Well } \\
\text { No. }\end{array}$ & $\begin{array}{c}\text { Formation } \\
\text { Depth, ft }\end{array}$ & $\mathbf{m i n} \mathbf{\Phi}$ & $\begin{array}{c}\mathbf{m a x} \\
\mathbf{\Phi}\end{array}$ & $\begin{array}{c}\text { Average } \\
\text { Porosity, \% }\end{array}$ & $\begin{array}{c}\mathbf{m i n} \\
\mathbf{S w}\end{array}$ & $\begin{array}{c}\mathbf{m a x} \\
\mathbf{S w}\end{array}$ & $\begin{array}{c}\text { Average } \\
\text { Sw, \% }\end{array}$ & $\begin{array}{c}\text { Average } \\
\text { Net Pay, } \\
\mathbf{f t}\end{array}$ & $\begin{array}{c}\text { Volume of } \\
\text { shale \% }\end{array}$ \\
\hline $\mathbf{1}$ & $13468-14330$ & 0.0045 & 0.235 & 11.4 & 0.2 & 0.98 & 22.2 & 756 & 14.80 \\
\hline $\mathbf{2}$ & $12921-14197$ & 0.0049 & 0.151 & 10.2 & 0.1 & 1.00 & 20 & 996 & 27.30 \\
\hline $\mathbf{3}$ & $13874-14300$ & 0.007 & 0.189 & 9.9 & 0.05 & 1.00 & 22 & 291 & 25.31 \\
\hline
\end{tabular}




\section{Discussion and Conclusions}

The quality of the reservoirs in the "Abu Attifel Field in Libya" under study is poor owing to the analysis of the petrophysical parameters determined from the three wells. The average porosity values are moderate and approximately the same, and have good permeability due to the presence of low volume of shale in the reservoir. The net pay thickness was determined considering the volume of shale cutoff, porosity cutoff and water saturation cutoff values to get an average net pay thickness for wells no. 1,2 and 3 to be 756 . ft, $996 \mathrm{ft}$ and $291 \mathrm{ft}$ respectively. In all, the part of the Abu Attifel Field in Libya under study have good prospect for exploration and production because of the high level of net pay thickness and low water saturation, and consequently high hydrocarbon saturations.

\section{References}

- Abbas, A.R. (2016). Basic Well Logging. [cited 2016 02-12]; Available from: http://www.petroleumbook.com/2016/10/basic-well-logging.html.

- $\quad$ Ahmed, T. (2010), reservoir engineering handbook. Fourth ed.: ELSEVIER.

- Bassiouni, Z. (1994), Theory, Measurement, and Interpretation of Well Logs. Vol. 4.: SPE Textbook Series. 4.

- Frailey, S. M., Damico, J. \& Leetaru, H. E. (2011). Reservoir characterization of the Mt. Simon Sandstone, Illinois Basin, USA. Energy Procedia 4, 5487-5494.

- Gomez, C. T., Dvorkin, J. \& Vanorio, T; (2010); Laboratory measurements of porosity, permeability, resistivity, and velocity on Fontainebleau sandstones; Geophysics 75, E191.

- Johnson, D.E. and K.E. Pile (2006), Well Logging in Nontechnical language. second ed.: PennWell.

- SERRA, O. 1984, Fundamentals of well-log interpretation first ed.: ELSEVIER.

- Tiab, D. and E. C.Donaldson (2004), petrophysics theory and practice of measuring reservoir rock and fluid transport properties. second ed.: elsevier.

- Whittaker, A., (1985) Coring Operations Procedures for Sampling and Analysis of Bottombole and Sidewall Cores.: D. Reidel Publishing Company. 174. 